УДК 625.72

\title{
SPECIFICS OF AUTOMOBILE DUAL WHEELS INTERACTION WITH THE SUPPORTING SURFACE
}

\author{
D. Leontiev, Assoc. Prof., Cand. Sc. (Eng.), E. Don, P. G., \\ Kharkov National Automobile and Highway University
}

\begin{abstract}
The article deals with the problem of double tire interraction with the road surface. The theory of elastic deformation of tires which are parallely arranged on one axis is given. Theoretical studies as for the description of the process of double tire interaction with the road surface are presented. Analysis of changes in the rigidity, depending on the humber of tires on the wheel is carried out.
\end{abstract}

Key words: dual wheels, tire, longitudinal force, tiring, resiliency, deformation, tire twist angle.

\section{ОСОБЕННОСТИ ВЗАИМОДЕЙСТВИЯ СДВОЕННЫХ АВТОМОБИЛЬНЫХ КОЛЁС С ОПОРНОЙ ПОВЕРХНОСТЬЮ}

\author{
Д.Н. Леонтьев, доц., с.н.с., к.т.н., Е.Ю. Дон, асп., \\ Харьковский национальный автомобильно-дорожный университет
}

\begin{abstract}
Аннотация. Рассмотрен вопрос взаимодействия автомобильных колес с опорной поверхностью. Проанализирована, а также обобщена информация о взаимодействии шин одинарных колес с опорной поверхностью. Раскрыта сущность взаимодействия шин сдвоенных колес транспортных средств на основе закона Гука и теории крипа.
\end{abstract}

Ключевые слова: сдвоенные колеса, иина, сила сиепления, ошиновка, эластичность, упругость, деформачия, угол закручивания шины.

\section{ОСОБЛИВОСТІ ВЗАЕМОДІї ЗДВОЕНИХ АВТОМОБІЛЬНИХ КОЛІС 3 ОПОРНОЮ ПОВЕРХНЕЮ}

\author{
Д.М. Леонтьєв, доц., с.н.с., к.т.н., Є.Ю. Дон, асп., \\ Харківський національний автомобільно-дорожній університет
}

Анотація. Розглянуто питання взаємодї автомобільних коліс з опорною поверхнею. Проаналізовано, а також узагальнено інформацію про взаємодію шин одинарних коліс з опорною поверхнею. Розкрито сутність взаємодії иин здвоєних коліс транспортного засобу на основі закону Гука та теорії кріпа.

Ключові слова: здвоєні колеса, шина, сила зчеплення, ошинування, еластичність, пружність, деформація, кут закручування иини.

\section{Introduction}

Interaction of the tire with a supporting surface is determined primarily by grip properties of the tire. In the theory of operational properties of automobiles and tractors, grip properties are characterized by grip being implemented $\left(f_{x}\right)$ (specific braking or pulling force), which changes with the change of automobile wheel motion parameters. Physical nature of the implemented grip is usually presented as a simple dependence (1)

$$
f_{x}=\frac{R_{x}}{R_{z}}
$$

In dependence (1), the longitudinal force of grip being implemented $\left(R_{x}\right)$ is not constant and de- 
pends on various factors: speed of translational movement of the wheel center, load per wheel $\left(R_{z}\right)$, air pressure in the tire $(p)$, tire design and material of which it is made, tread pattern and degree of its wear, moment of wheel inertia, value of supplied braking torque, as well as type and condition of the road surface. Therefore, its value is of interest to the automotive industry researchers.

\section{Analysis of publications}

In scientific papers $[2,7-10]$, the implemented longitudinal grip force is often taken as a function of wheel slip $S$ [2]. The graph of $R_{x}=f(S)$ function is called $« R_{x}-S$ diagram». Its visual image is presented in Fig. 1.

It is known that the curve of change in longitudinal grip force being implemented has characteristically expressed points (Fig. 1). It is obvious that in order to plot a curve, which characterizes grip, it is necessary to know the value of these characteristically expressed points; but in practice, in most cases their values are unknown, which complicates the process of modeling the vehicle movement dynamics.

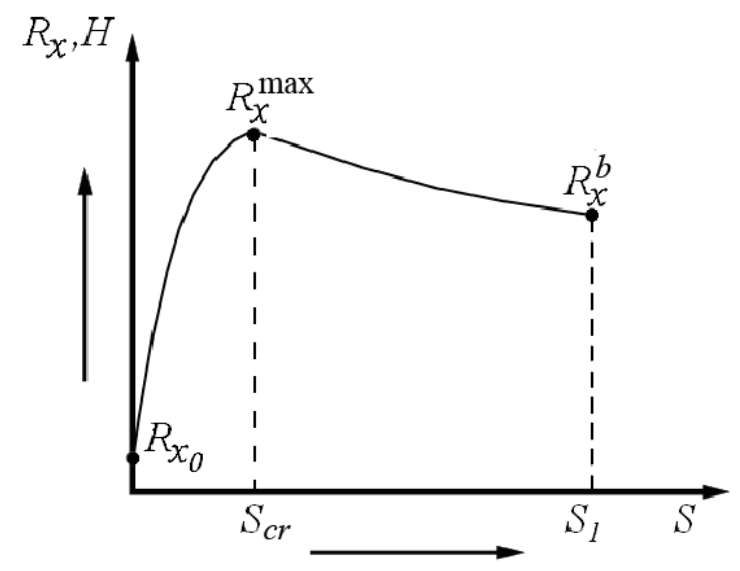

Fig. 1. The curve of change in the longitudinal grip force implemented between the tire and the supporting surface: $R_{x_{0}}$ is rolling resistance force with free rolling of the wheel; $R_{x}^{\max }$ is maximum grip force implemented between the wheel and the supporting surface at critical slip (slipping) $S_{c r} \approx 0,15 \div 0,3 ; R_{x}^{b}$ is grip force implemented between the wheel and the supporting surface at full slip (slipping) $S_{1}=1$

Analyzing the alternative methods for description of longitudinal grip force implemented be- tween the wheel and the supporting surface, we paid attention to the method which is based on the theory of creep [3, 4]. This method allows determining the longitudinal grip force implemented between the wheel and the supporting surface on the basis of torsional stiffness and angular deformation of a pneumatic tire.

The method based on the creep theory is founded on the assumption that the force implemented in the patch of contact of the tire and the supporting surface is defined as the product of torsional stiffness of the tire and its twist angle referred to the dynamic radius of the wheel $[3,4]$

$$
R_{x}=\frac{C_{x} \cdot \xi_{x}}{r_{d}}
$$

where $C_{x}$ is the torsional stiffness of the tire, $\mathrm{N} \cdot \mathrm{m} / \mathrm{rad} ; \xi_{x}$ is the twist angle of the tire, rad; $r_{d}$ is the radius of the wheel, $\mathrm{m}$.

The parameters used in dependence (2) are not an innovation; they are regulated by the standards of different countries $[5,6]$.

The analysis of scientific and technical literature showed that the torsional stiffness of the tire and its twist angle can be determined from dependencies 3 and 4 respectively, which are offered by the authors of papers $[3,4]$.

$$
\begin{gathered}
C_{X}=\left(100-\frac{A_{0}}{g \cdot C_{X}^{p_{\max }}} \cdot e^{-10 \cdot A_{1} \cdot p^{2}}\right) \times \\
\times\left(635 \cdot \ln \left(R_{z}\right)-5060\right) ; \\
\xi_{x}=\frac{a_{0}^{\xi} \cdot S}{b_{0}^{\xi}+c_{0}^{\xi} \cdot S+S^{2}}+\xi_{0} .
\end{gathered}
$$

To determine the torsional stiffness in dependence (3), operating parameters of the tire are used: tire pressure $(p)$ and tire stiffness limit value, which determine $A_{0}$ and $A_{1}$ coefficients and load per wheel $\left(R_{z}\right)$.

In determining the twist angle, the authors of papers $[3,4]$ suggest an uncomplicated dependence, which characterizes the interaction of the wheel with the supporting surface and can be solved without the use of complex mathematical approaches and methods. 
The analysis of scientific and technical literature $[8,9,12-14]$ and state standards of different countries across the world $[5,6]$, showed that there are no theoretical advances as to the determination of the grip force implemented by the interaction of dual, wide-profile or triplex wheels. It was only established in the analysis, that only the questions of vertical load distribution between the wheels of such type as part of a wheeled vehicle (WV), and the impact of this load on the road surface are theoretically considered. So, the paper suggests considering the nature of the phenomenon of implementation of the grip force, which occurs as a result of dual wheels braking.

\section{Purpose and problem statement}

The purpose of the article is to disclose the key point of the feature of dual wheels interaction with the road surface on the basis of elastic and deformation properties of pneumatic tires.

\section{Interacting weels to the surface}

While considering the braking of dual wheels of a cargo WV, let us use the well-known Hooke's law for parallel elastic bodies [15]. For this purpose, let us present the dual wheels (Fig. 2, a) in the form of two elastic bodies (Fig. 2, b) having corresponding degrees of stiffness in the longitudinal direction, which are equivalent to the torsional stiffness of each dual wheel.

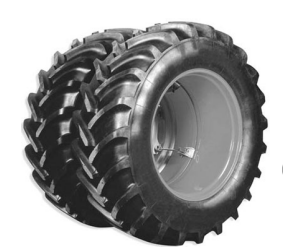

a

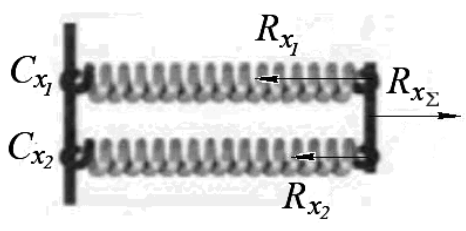

b
Fig. 2. Model of dual wheel braking

With such arrangement of the elastic bodies, let us assume that the angular twisting of the tire (Fig. 3) will be equal on all parallel tires; and the angular stiffness according to Hooke's law - will be added. Then the total force $\left(R_{x_{\Sigma}}\right)$ implemented under the dual wheels will also be formed by two forces implemented by separate tires of the WV dual wheel $\left(R_{x_{1}}\right.$ and $R_{x_{2}}$ ). The total force value cannot be implemented more than the maximum braking force $\left(R_{x}^{\max }\right)$, which is implemented between the relevant type of the tire and the supporting surface. It is evidenced by the experimental studies given in paper [1] in case of dual wheels braking on the verge of blocking.

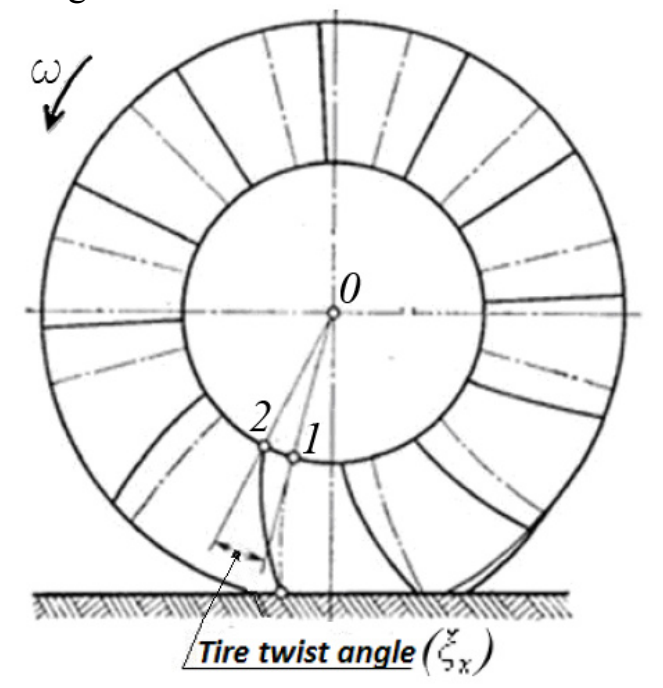

Fig. 3. Twisting $\left(\xi_{x}\right)$ of the tire during braking

The analysis of the experimental studies which are conducted in paper $[1,4]$ showed that the maximum values of the implemented force are described by equation (5)

$$
R_{x}^{\max }=\frac{C_{x} \cdot \xi_{x}^{\max }}{r_{d}} .
$$

If we accept the assumption specified earlier, then we can write down the equation which will determine the maximum grip force implemented between the dual wheel and the supporting surface in the following form

$$
R_{x 2}^{\max }=\frac{\left(C_{x 1}+C_{x 2}\right) \cdot \xi_{x 2}^{\max }}{r_{d}} .
$$

Because dual tires will not be able to implement greater braking force than $\left(R_{x}^{\max }\right)[1,4]$, let us equate equation (6) to equation (5), as a result of which we get the following dependence

$$
\xi_{x 2}^{\max }=\frac{C_{x} \cdot \xi_{x}^{\max }}{C_{x 1}+C_{x 2}} .
$$

Similarly, for the tires with triple tiring, the twisting angle equation takes the following form

$$
\xi_{x 3}^{\max }=\frac{C_{x} \cdot \xi_{x}^{\max }}{C_{x 1}+C_{x 2}+C_{x 3}} .
$$


By analyzing dependences (7) and (8), it can be concluded that the increase in the number of tires on weel with one braking mechanism leads to reduction in their maximum twist angle with regard to the same single wheel, because the tire becomes stiffer. In general terms, the nature of change in dual wheels twist angle can be presented as shown in Fig. 4.

Such physical phenomenon leads, for example, to premature rear wheels blocking with the identical braking mechanisms and characteristics of braking drive circuits. To avoid this phenomenon, it is necessary to increase pressure in the front wheels tires (or reduce pressure in the rear wheels tires), thereby, at the expense of tire stiffness, compensating the growth rate of the braking force between the dual wheels and the supporting surface relative to the growth rate of the braking force on the front wheels.

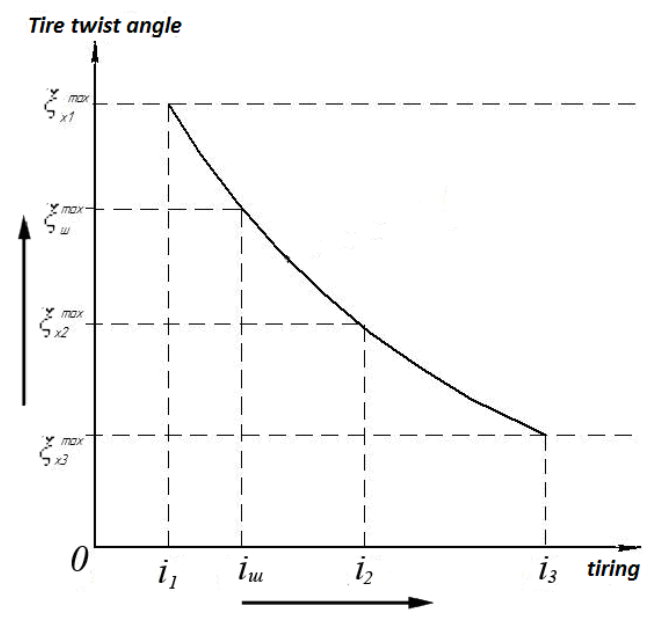

Fig. 4. Nature of change in the tires twist angle in relation to $\mathrm{WV}$ wheels tiring $\left(i_{n}\right)$

In general terms, the equation describing the twist angle change because of wheels tiring $\left(i_{n}>1\right)$ can be presented in the following form

$$
\xi_{x i_{n}}^{\max }=B_{0} e^{B_{1} \cdot i_{n}}
$$

where $i_{n}$ is the number of tires (tiring); $B_{0}$ and $B_{1}$ are coefficients, which are calculated respectively as follows

$$
B_{0}=\frac{\xi_{x}^{\max }}{e^{B_{1}}}, B_{1}=\frac{\ln \left(\frac{\xi_{x i_{3}}^{\max }}{\xi_{x}^{\max }}\right)}{2}
$$

where $\xi_{x i_{3}}^{\max }$ is the triplex tires twist angle.

It should be noted that with the use of wideprofile tires, $i_{n}$ value can be a non-integral number greater than one.

\section{Conclusions}

Using Hooke's law and the creep theory in the analysis of interaction of dual, wide-profile or triplex wheels allowed revealing the following:

- increasing the number of tires on one braking mechanism leads to reduction in their maximum twist angle with respect to the twist angle of the similar single wheel;

- dual wheels mounting leads to premature blocking of rear wheels under pressures in their tires close to the tire pressure in the wheels of the front axle of the car.

The suggested dependences allow clarifying the theoretical foundations of the dynamics of movement of vehicles which have dual, triplex or wide-profile tiring of the rear axle wheels.

\section{References}

1. Леонтьев Д.Н. Системный подход к созданию автоматизированного тормозного управления транспортных средств категорий M3 и N3: дис. ... канд. техн. наук: 05.22.02 / Дмитрий Николаевич Леонтьев. - Харьков, 2011. - 241 с.

2. Основы создания и исследования электронно-пневматического тормозного управления транспортных средств: монография / А.Н. Туренко, В.И. Клименко, Л.А. Рыжих и др. - Х.: ХНАДУ, 2012. $-288 \mathrm{c}$.

3. Леонтьев Д.Н. Определение продольной реализуемой силы сцепления автомобильного колеса с опорной поверхностью по крутильной деформации шины и ее жесткости / Д.Н. Леонтьев, Л.А. Рыжих, А.В. Быкодоров // Автомобильная промышленность. - 2014. - №10. C. 20-25.

4. Реализация интеллектуальных функций в электронно-пневматическом тормозном управлении транспортных средств: монография / А.Н. Туренко, В.И. Клименко, Л.А. Рыжих и др. - Х.: ХНАДУ, 2015. $-450 \mathrm{c}$. 
5. Tires and traction. SAE J670 200801. [Действующий от 24.01.2008]. - Vehicle Dynamics Committee. -42 p.

6. Шины пневматические, конструкция. Термины и определения: ГОСТ-22374-77. - [Действующий от 21.02.1977 №428. Изменен 01.01.1978]. - М.: Издательство стандартов. -42 с.

7. Mark Denny The dynamics of antilock brake systems / Mark Denny // European Journal of Physics. - 2005. - Vol. 26, №6. - P. 1007-1016.

8. Pacejka H.B. Magic Formula Tyre Model with Transient Properties / H.B. Pacejka, I.J.M. Besselink. - Lisse: Swets \& Zeitlinger B.V., 1997. - P. 234-249.

9. Burckhardt M. Erfahrungen bei der Konzeption und Entwicklung des MercedesBenz / M. Burckhardt / Bosch - AntiBlockier-Systems (ABS) // Automobiltechnische Zeitschrift. - 1979. - Bd. 81.Vol. 5. - P. 201-208.

10. Леонтьєв Д.М. Методи розрахунку коефіцієнту зчеплення, що реалізується при коченні колеса в гальмівному режимі / Д.М. Леонтьєв, Л.О. Рижих, О.В. Бикадоров та ін. // Автомобильный транспорт: сб. науч. тр. - 2010. Вып. 27. - С. 7-12.

11. Левин М.А. Теория качения деформированного колеса / М.А. Левин, Н.А. Фуфаев. - М.: Наука, 1989. - 268 с.

12. Кнороз В.И. Работа автомобильной шины / В.И. Кнороз. - М.: Транспорт, 1976. $-240 \mathrm{c}$.

13. Литвинов А.С. Управляемость и устойчивость автомобиля / А.С. Литвинов. М.: Машиностроение, 1971. - 416 с.

14. Фалькевич Б.С. Теория автомобиля: учебное пособие / Б.С. Фалькевич. - 2-е изд. перер. - М.: Машгиз, 1963. - 243 с.

15. Прохоров А.М. Физическая энциклопедия: в 5 т. / Главный редактор А.М. Прохоров. - М.: Советская энциклопедия, 1988. - Режим доступа к сайту: http://allphysics.narod.ru.

\section{References}

1. Leontiev D.N. Sistemnyiy podhod $k$ sozdaniyu avtomatizirovannogo tormoznogo upravleniya transportnyih sredstv kategoriy M3 $i$ N3 [Systematic approach to the creation of the automated brake control for vehicles of M3 and N3 categories]. Dis. ...kand. tehn. nuk.: 05.22.02. Kharkov. 2011. $241 \mathrm{p}$.
2. Turenko A.N., Klimenko V.I., Leontiev D.N. Osnovyi sozdaniya $i$ issledovaniya elektronno-pnevmaticheskogo tormoznogo upravleniya transportnyih sredstv [Basis for creation and research of electronic-pneumatic brake control of vehicles]. Kharkov, KhNADU Publ., 2012. $288 \mathrm{p}$.

3. Leontiev D.N., Ryizhih L.A., Byikodorov A.V. Opredelenie prodolnoy realizuemoy silyi stsepleniya avtomobilnogo kolesa s opornoy poverhnostyu po krutilnoy deformatsii shinyi $i$ ee zhestkosti [Determination of the longitudinal implemented force of automobile wheel grip with a supporting surface by the torsional deformation of a tire and its stiffness]. Avtomobilnaya promyishlennost, 2014. no. 10. pp. 20-25.

4. Turenko A.N., Klimenko V.I., Leontiev D.N. Realizatsiya intellektualnyih funktsiy $v$ elektronno-pnevmaticheskom tormoznom upravlenii transportnyih sredstv [Implementation of intelligence functions in electronic-pneumatic brake control of vehicles]. Kharkov, KhNADU Publ., 2015. $450 \mathrm{p}$.

5. Tires and traction. SAE J670_200801. [Effective from January 24, 2008]. Vehicle Dynamics Committee. 42 p.

6. Shinyi pnevmaticheskie, konstruktsiya. Terminyi $i$ opredeleniya [Pneumatic tires, structure. Terms and definitions] GOST22374-77. [Deystvuyuschiy ot 21.02.1977 №428. Izmenen 01.01.1978]. Moscow, Izdatelstvo standartov Publ., $42 \mathrm{p}$.

7. Mark Denny The dynamics of antilock brake systems. European Journal of Physics. 2005. Vol. 26, no. 6. pp. 1007-1016.

8. Pacejka, H.B., Besselink, I.J.M. Magic Formula Tyre Model with Transient Properties. Lisse: Swets \& Zeitlinger B.V., 1997. pp. 234-249.

9. Burckhardt M. Erfahrungen bei der Konzeption und Entwicklung des MercedesBenz. Bosch - Anti-Blockier-Systems (ABS). Automobiltechnische Zeitschrift. 1979. Bd. 81. Vol. 5. pp. 201-208.

10. Leontiev D., Ryzhykh L., Bykadorov O. Metody rozrakhunku koefitsiientu zcheplennia, shcho realizuietsia pry kochenni kolesa v halmivnomu rezhymi [Methods for calculating the coefficient of grip implemented at wheel rolling in braking mode]. Avtomobilnyi transport. 2010. Vol. 27. pp. 7-12. 
11. Levin M.A., Fufaev N.A. Teoriya kacheniya deformirovannogo kolesa [Theory of deformed wheel rolling]. Moscow, Nauka Publ., 1989. 269 p.

12. Knoroz V.I. Rabota avtomobilnoy shinyi. [Automobile tire operation]. Moscow, Transport Publ., 1976. 239 p.

13. Litvinov A.S. Upravlyaemost i ustoychivost avtomobilya [Handling and stability of a car]. Moscow, Mashinostroenie Publ., $1971.416 \mathrm{p}$.

14. Falkevich B.S. Teoriya avtomobilya. (uchebnoe posobie, izd. 2-e pererabotannoe) [Car theory. (study guide, 2nd edition, revised)]. Moscow, Mashgiz Publ., 1963. $243 \mathrm{p}$.

15. Prohorov A.M. Fizicheskaya entsiklopediya [Physical encyclopedia] (V 5 Tomah). Moscow, Sovetskaya entsiklopediya Publ., 1988. Avialable at: http://allphysics.narod. ru.

Рецензент: М.А. Подригало, профессор, д.т.н., ХНАДУ 